\title{
THE EFFECT OF HEALTH LITERACY ON OBSTETRIC DECISIONS OF WOMEN IN REPRODUCTIVE AGE
}

Esra BESIR MAHSUN ${ }^{1}$, Hakan DEMIRCl²

${ }^{1}$ Marma ra Integrated Hospital, Balikesir, TURKEY

2 Department of Family Me dicine, Unive rsity of Health Sciences Turkey Bursa Yuksek I htisas Training a nd Research Hospital, Bursa, TURKEY

\begin{abstract}
Aim In this study, it was aimed to investigate the effects of health literacy on obstetric decisions in women of reproductive age living in our region.

Methods: This study was carried out on 400 registered women aged 15-49 who voluntarily participated in the survey in January 2018 - April 2018 period. In the survey, a questionnaire questioning the sociodemographic characteristics of the patients and a Turkish translated Health Literacy Survey-European Union (HLS-EU-47) questionnaire were used to measure the level of health literacy.

Results: As a result of the research, in the reproductive age women living in our region, the health literacy was determined as $7.5 \%$ adequate / excellent. Mothers who breastfed their baby for 12 months were found to have higher levels of health literacy in terms of disease prevention than those who did not breastfeed or who breastfed for longer than 12 months $(p=0.022)$. The educational status of women was correlated with HLS-EU-47 scores $(p<0.001)$. Those with good income have higher scores on HLSEU-47 ( $p<0.001$ ). Health literacy was not found to have an impact on obstetric decisions to have OGTT and tetanus vaccination and influenza vaccination in pregnancy ( $p=0.106 ; 0.362 ; 0.123$ respectively). Participants who had a double screening test were found to have higher HLS-EU-47 scores in terms of disease prevention ( $p=0.005)$.

Conclusions: The rates of health literacy are quite low in women of reproductive age in our region. The impact of health literacy on obstetric decisions is shown in the study. Improving health literacy in wome $n$ will have a direct impact on family health especially in terms of disease prevention.

Keywords: Breastfeeding, double screening test, health literacy, pregnancy, vaccination
\end{abstract}

Corresponding Author: Esra BESIR MAHSUN eabesir@gmail.com

Received: July 23, 2021; Accepted: August 15, 2021; Published Online: August 30, 2021

Cite this article as: Besir, Mahsun, E. \& Demirci, H. (2021). The effect of health literacy on obstetric decisions of women in reproductive age. European Health Literacy Journal 2(2), 15-25. 


\section{Introduction}

Health literacy level of women affects their behaviors of protecting and improving their health. As the woman's rate of understanding and using the information about her health increases, her behaviors of preventing diseases and providing early diagnosis increases as well (1-3).

In the literature, it is also stated that health literacy level of women affects their behaviors of protection from cancer. In previous studies, it has been reported that the rate of women's understanding of the aim, importance and screening methods of cervical cancer was low in women with low health literacy $(4,5)$. Similarly, importance of health literacy in breast cancer screening has been exhibited in researches (6).

It has been detected that, pregnant women with low health literacy level have a lower understanding of pregnancy screening tests with respect to those with high health literacy level $(7,8)$. One of the effective factors in disease prevention is vaccination program (9). Individuals with low health literacy levels may not fully understand the aim and importance of the vaccines. This situation can affect their vaccination rates. It has been demonstrated in the studies that, rate of non-vaccination against influenza and pneumonia was higher among individuals with low health literacy level (10). Increasing women's health literacy levels must be handled in a vital way as it will provide complete and accurate vaccination of both themselves and their children.

It is important for women to have information about pregnancy and delivery in order to manage the decisions taken during this process. However, many women don't understand the medical instructions or prescriptions given by the physicians during this process. This situation leads to an unhealthy pregnancy and delivery and ends up with an undesirable maternity experience $(11,12)$. It also assumed that women's health literacy is effective in their contraception preferences. Similarly, HL has been found to be associated with breastfeeding durations $(13,14)$.

In this study, it was aimed to investigate the effects of health literacy on obstetric decisions in women of reproductive age living in our region.

\section{Methods}

The population of the research comprised of 400 female patients between age 15-49 registered to Bursa Yüksek İhtisas Training and Research Hospital Bağlaraltı Training Family Health Center in the period of January 2018-April 2018. Ministry of Health, İstanbul Kartal Dr. Lutfi Kırdar Training and Research Hospital, Clinic Research Ethics Committee has approved this dissertation study titled "The Effect of Health Literacy on Obstetric Decisions of Women in Reproductive Age between 15-49, Registered to a Training Family Health Center" with the decision and permission dated 10.12.2017, no: 2011-KAEK-25 2016/14-11. Written consents were received from the patients and the research was conducted with survey method.

\section{Inclusion Criteria}

1. Registered to Bağlaraltı Training Family Health Center,

2. Accepted to participate in the study,

3. Female between age15-49

4. Literate

Survey Forms Used

In this research, a questionnaire interrogating the patients' socio-demographic characteristics and Turkish translation of Health Literacy Survey European 
Union (HLS-EU) to measure the health literacy level were used.

Socio-demographic data of the participants were recorded. Oral Glucose Tolerance Test (OGTT) 50 g refusal of women during pregnancy, tetanus vaccination states during pregnancy, double screening and triple screening test implementation during pregnancy, contraception preferences were recorded.

Height and weight among anthropometric measurements were measured with standard measuring tools. The participants were asked to take of their shoes during height measurement. They were also asked to wear light clothes during weight measurement. BMI: Body mass index value was calculated by dividing the patient's weight by the square of his/her height $\left(\mathrm{kg} / \mathrm{m}^{2}\right)$.

\section{Statistical Analysis}

The conformity of the variables to normal distribution was analyzed with Shapiro Wilk test. Continuous variables were expressed with mean \pm standard deviation and median (minimum: maximum) values. Categorical variables were expressed with $n$ (\%). According to the results of the normality test, Mann Whitney $U$ test was used for comparisons between two

\section{Table 1. Socio-demographic characteristics of the participants}

\begin{tabular}{|l|l|}
\hline & $\mathrm{n}=400$ \\
\hline Age (years) & $33.26 \pm 7.25(15: 49)$ \\
\hline Marital Status & \\
\hline Married & $347(86.80 \%)$ \\
\hline Single & $53(11.50 \%)$ \\
\hline Education & \\
\hline Primary School & $144(34.30 \%)$ \\
\hline Secondary School & $82(20.50 \%)$ \\
\hline High School & $174(24.80 \%)$ \\
\hline & \\
\hline
\end{tabular}




\begin{tabular}{|l|l|}
\hline Economic Level & \\
\hline Bad & $26(5.80 \%)$ \\
\hline Moderate & $242(60.50 \%)$ \\
\hline Good & $132(30.50 \%)$ \\
\hline Occupation & \\
\hline Housewife & $278(69.50 \%)$ \\
\hline Worker & $30(7.50 \%)$ \\
\hline Teacher & $28(7 \%)$ \\
\hline Student & $23(5.80 \%)$ \\
\hline Officer & $17(4.30 \%)$ \\
\hline Profeccional Occupation & $10(2.50 \%)$ \\
\hline Craft & $6(1.50 \%)$ \\
\hline Others & $8(2.10 \%)$ \\
\hline
\end{tabular}

Data is given as $n$ (\%).

Health literacy sub-group distribution of the participants is given in Table 2. According to this table, in our region was found adequate and excellent at a rate of $7.50 \%$. health literacy level of the women in reproductive age

Table 2. Distribution of health literacy sub-groups

\begin{tabular}{|l|l|}
\hline & \\
\hline Groups (Scores) & $\mathbf{n = 4 0 0}$ \\
\hline $\begin{array}{l}\text { Inadequate Health Literacy } \\
(\mathbf{0 - 2 5})\end{array}$ & $29(7.20 \%)$ \\
\hline $\begin{array}{l}\text { Limited Health Literacy } \\
\text { (>25-33) }\end{array}$ & $341(85.30 \%)$ \\
\hline $\begin{array}{l}\text { Adequate Health Literacy } \\
\text { (>33-42) }\end{array}$ & $24(6 \%)$ \\
\hline $\begin{array}{l}\text { Excellent Health Literacy } \\
\text { (>42-50) }\end{array}$ & $6(1.50 \%)$ \\
\hline
\end{tabular}

Data is given as $n(\%)$,

Relationship of the participants' health literacy and obstetric parameters is given in Table 3. A difference was observed in terms of disease prevention scores between the participants who had and hadn't undergone double screening test. It has been detected that disease prevention score was higher in those who had undergone double screening test. 
Table 3. Relationship of health literacy with obstetric parameters

\begin{tabular}{|c|c|c|c|c|}
\hline & $\begin{array}{l}\text { HealthcareService } \\
\text { (Questions 1-16) }\end{array}$ & $\begin{array}{l}\text { Disease } \\
\text { Prevention } \\
\text { (Questions 17-31) }\end{array}$ & $\begin{array}{l}\text { Health } \\
\text { Promotion } \\
\text { (Questions 32-47) }\end{array}$ & $\begin{array}{l}\text { General } \\
\text { (Questions1-47) }\end{array}$ \\
\hline \multicolumn{5}{|c|}{ Oral Glucose Tolerance Test $(50 \mathrm{~g})$} \\
\hline No $(n=180)$ & $\begin{array}{l}32.81 \\
(8.33: 50) \\
31.49 \pm 4.75\end{array}$ & $\begin{array}{l}26.67 \\
(13.33: 50) \\
27.31 \pm 4.90\end{array}$ & $\begin{array}{l}30.21 \\
(8.33: 50) \\
29.97 \pm 4.64\end{array}$ & $\begin{array}{l}29.79 \\
(11.35: 48.23) \\
29.64 \pm 4.17\end{array}$ \\
\hline $\operatorname{Yes}(n=218)$ & $\begin{array}{l}33.33 \\
(15.63: 50) \\
32.16+3.99\end{array}$ & $\begin{array}{l}27.78 \\
(12.22: 45.56) \\
28.81 \pm 4.06\end{array}$ & $\begin{array}{l}30.21 \\
(16.67: 43.75) \\
29.81 \pm 3.14\end{array}$ & $\begin{array}{l}30.14 \\
(16.31: 45.04) \\
29.97 \pm 3.10\end{array}$ \\
\hline p-value & $0.123^{\mathrm{a}}$ & $0.051^{\mathrm{a}}$ & $0.695^{\mathrm{a}}$ & $0.106^{\mathrm{a}}$ \\
\hline \multicolumn{5}{|c|}{ Tetanus Vaccination } \\
\hline No $(n=113)$ & $\begin{array}{l}32.29 \\
(15.63: 50) \\
31.33 \pm 4.40\end{array}$ & $\begin{array}{l}26.67 \\
(13.33: 42.22) \\
27.05 \pm 4.15\end{array}$ & $\begin{array}{l}30.21 \\
(14.58: 44.79) \\
29.81 \pm 4.12\end{array}$ & $\begin{array}{l}30.14 \\
(16.31: 43.62) \\
29.45 \pm 3.46\end{array}$ \\
\hline Yes $(n=285)$ & $\begin{array}{l}33.33 \\
(8.33: 50) \\
32.06 \pm 4.34\end{array}$ & $\begin{array}{l}27.78 \\
(12.22: 50) \\
27.79 \pm 4.57\end{array}$ & $\begin{array}{l}30.21 \\
(8.33: 50) \\
29.91 \pm 3.80\end{array}$ & $\begin{array}{l}30.14 \\
(11.35: 48.23) \\
29.97 \pm 3.68\end{array}$ \\
\hline p-value & $0.193^{\mathrm{a}}$ & $0.90^{\mathrm{a}}$ & $0.326^{\mathrm{a}}$ & $0.362^{\mathrm{a}}$ \\
\hline \multicolumn{5}{|c|}{ Influenza Vaccination } \\
\hline No $(n=391)$ & $\begin{array}{l}33.33 \\
(8.33: 50) \\
31.84 \pm 4.39\end{array}$ & $\begin{array}{l}27.78 \\
(12.2: 50) \\
27.53 \pm 4.46\end{array}$ & $\begin{array}{l}30.21 \\
(8.33: 50) \\
29.85 \pm 3.89\end{array}$ & $\begin{array}{l}30.14 \\
(11.35: 48.23) \\
29.79 \pm 3.63\end{array}$ \\
\hline Yes $(n=7)$ & $\begin{array}{l}33.33 \\
(30.21: 36.46) \\
32.88 \pm 1.98\end{array}$ & $\begin{array}{l}31.11 \\
(24.44: 35.56) \\
30.32 \pm 4.04\end{array}$ & $\begin{array}{l}30.21 \\
(28.13: 39.58) \\
31.40 \pm 3.77\end{array}$ & $\begin{array}{l}31.21 \\
(28.37: 37.23) \\
31.56 \pm 2.82\end{array}$ \\
\hline p-value & $0.619^{\mathrm{a}}$ & $0.066^{\mathrm{a}}$ & $0.538^{\mathrm{a}}$ & $0.123^{\mathrm{a}}$ \\
\hline \multicolumn{5}{|c|}{ Contraception } \\
\hline No $(n=125)$ & $\begin{array}{l}33.33 \\
(15.63: 48.96) \\
31.42 \pm 4.11\end{array}$ & $\begin{array}{l}26.67 \\
(12.22: 50) \\
27.03 \pm 4.65\end{array}$ & $\begin{array}{l}30.21 \\
(14.58: 42.71) \\
29.56 \pm 3.81\end{array}$ & $\begin{array}{l}29.79 \\
(18.79: 47.16) \\
29.38 \pm 3.50\end{array}$ \\
\hline Yes $(n=273)$ & $\begin{array}{l}33.33(8.33: 50) \\
32.05 \pm 4.47\end{array}$ & $\begin{array}{l}27.78(13.33: 46.67) \\
27.84 \pm 4.36\end{array}$ & $\begin{array}{l}30.21(8.33: 50) \\
30.03 \pm 3.92\end{array}$ & $\begin{array}{l}30.14(11.35: 48.23) \\
30.02 \pm 3.67\end{array}$ \\
\hline p-values & $0.575^{\mathrm{a}}$ & $0.077^{\mathrm{a}}$ & $0.499^{\mathrm{a}}$ & $0.207^{\mathrm{a}}$ \\
\hline
\end{tabular}




\begin{tabular}{|c|c|c|c|c|}
\hline \multicolumn{5}{|l|}{ Breastfeeding } \\
\hline No $(n=125)$ & $\begin{array}{l}33.33 \\
(15.63: 48.96) \\
31.42 \pm 4.11\end{array}$ & $\begin{array}{l}26.67 \\
(12.22: 50) \\
27.03 \pm 4.65\end{array}$ & $\begin{array}{l}30.21 \\
(14.58: 42.71) \\
29.56 \pm 3.81\end{array}$ & $\begin{array}{l}29.79 \\
(18.79: 47.16) \\
29.38 \pm 3.50\end{array}$ \\
\hline $1-12$ months $(n=225)$ & $\begin{array}{l}33.33 \\
(15.63: 50) \\
32.24 \pm 4.28\end{array}$ & $\begin{array}{l}27.78 \\
(15.56: 46.67) \\
28.10 \pm 4.24\end{array}$ & $\begin{array}{l}30.21 \\
(16.67: 50) \\
30.23 \pm 3.54\end{array}$ & $\begin{array}{l}30.14 \\
(16.31: 48.23) \\
30.23 \pm 3.41\end{array}$ \\
\hline$>12$ months $(\mathrm{n}=48)$ & $\begin{array}{l}33.33 \\
(8.33: 43.75) \\
31.21 \pm 5.20\end{array}$ & $\begin{array}{l}6.67 \\
(13.33: 42.22) \\
26.60 \pm 4.74\end{array}$ & $\begin{array}{l}30.21 \\
(8.33: 44.79) \\
29.08 \pm 5.28\end{array}$ & $\begin{array}{l}29.79(11.35: 43.62) \\
29.01 \pm 4,59\end{array}$ \\
\hline p-values & $0.800^{\mathrm{b}}$ & $0.022^{b}$ & $0.386^{\mathrm{b}}$ & $0.101^{\mathrm{b}}$ \\
\hline \multicolumn{5}{|l|}{ Double screening test } \\
\hline No $(n=209)$ & $\begin{array}{l}33.33 \\
(8.33: 50) \\
31.39 \pm 4.73\end{array}$ & $\begin{array}{l}26.67 \\
(15.56: 50) \\
27.13 \pm 4.41\end{array}$ & $\begin{array}{l}30.21 \\
(8.33: 50) \\
29.78 \pm 4.43\end{array}$ & $\begin{array}{l}30.14 \\
(11.35: 47.52) \\
29.49 \pm 3.95\end{array}$ \\
\hline$Y e s(n=188)$ & $\begin{array}{l}33.33 \\
(17.71: 50) \\
32.36 \pm 3.87\end{array}$ & $\begin{array}{l}27.78 \\
(12.22: 46.67) \\
28.09 \pm 4.49\end{array}$ & $\begin{array}{l}30.21 \\
(16.67: 47.92) \\
29.99 \pm 3.19\end{array}$ & $\begin{array}{l}30.14 \\
(19.50: 48.23) \\
30.19 \pm 3.20\end{array}$ \\
\hline p-values & $0.073^{\mathrm{a}}$ & $\mathbf{0 . 0 0 5}^{\mathrm{a}}$ & $0.708^{\mathrm{a}}$ & $0.138^{\mathrm{a}}$ \\
\hline \multicolumn{5}{|l|}{ Triple screening test } \\
\hline No $(n=230)$ & $\begin{array}{l}33.33 \\
(8.33: 50) \\
31.62 \pm 4.81\end{array}$ & $\begin{array}{l}27.78 \\
(15.56: 46.67) \\
27.40 \pm 4.63\end{array}$ & $\begin{array}{l}30.21 \\
(8.33: 50) \\
29.88 \pm 4.64\end{array}$ & $\begin{array}{l}30.14 \\
(11.35: 48.23) \\
29.68 \pm 4.09\end{array}$ \\
\hline Yes $(n=168)$ & $\begin{array}{l}33.33 \\
(15.63: 48.96) \\
32.18 \pm 3.65\end{array}$ & $\begin{array}{l}27.78 \\
(12.22: 50) \\
27.83 \pm 4.22\end{array}$ & $\begin{array}{l}30.21 \\
(22.92: 42.71) \\
29.88 \pm 2.51\end{array}$ & $\begin{array}{l}30.14 \\
(19.86: 47.16) \\
30.01 \pm 2.86\end{array}$ \\
\hline p-values & $0.176^{\mathrm{a}}$ & $0.141^{\mathrm{a}}$ & $0.284^{\mathrm{a}}$ & $0.619^{\mathrm{a}}$ \\
\hline \multicolumn{5}{|l|}{ Education } \\
\hline $\begin{array}{l}\text { Primary School } \\
(n=142)\end{array}$ & $\begin{array}{l}31.25 \\
(8.33: 40.63) \\
30.30 \pm 4.85\end{array}$ & $\begin{array}{l}26.67 \\
(12.22: 36.67) \\
25.97 \pm 4.49\end{array}$ & $\begin{array}{l}30.21 \\
(8.33: 2.22) \\
28.84 \pm 3.80\end{array}$ & $\begin{array}{l}29.08 \\
(11.35: 35.46) \\
28.42 \pm 3.63\end{array}$ \\
\hline $\begin{array}{l}\text { Secondary School } \\
(n=82)\end{array}$ & $\begin{array}{l}33.33 \\
(20.83: 43.75) \\
31.53 \pm 3.24\end{array}$ & $\begin{array}{l}26,67 \\
(18.89: 42.22) \\
26.56 \pm 3.50\end{array}$ & $\begin{array}{l}30.21 \\
(14.58: 50) \\
29.41 \pm 4.36\end{array}$ & $\begin{array}{l}29.79 \\
(18.79: 43.62) \\
29.22 \pm 3.15\end{array}$ \\
\hline
\end{tabular}




\begin{tabular}{|c|c|c|c|c|}
\hline $\begin{array}{l}\text { High School } \\
(n=99)\end{array}$ & $\begin{array}{l}33.33 \\
(21.88: 50) \\
32.81 \pm 3.44\end{array}$ & $\begin{array}{l}28.89 \\
(20: 45.56) \\
28.70 \pm 3.30\end{array}$ & $\begin{array}{l}30.21 \\
(16.67: 43.75) \\
30.48 \pm 2.91\end{array}$ & $\begin{array}{l}30.50 \\
(23.40: 45.04) \\
30.70 \pm 2.53\end{array}$ \\
\hline $\begin{array}{l}\text { University } \\
(n=75)\end{array}$ & $\begin{array}{l}33.33 \\
(27.08: 50) \\
33.89 \pm 4.46\end{array}$ & $\begin{array}{l}28.89 \\
(23.33: 50) \\
30.28 \pm 5.03\end{array}$ & $\begin{array}{l}31.25 \\
(22.92: 47.92) \\
31.56 \pm 3.99\end{array}$ & $\begin{array}{l}31.21 \\
(26.24: 48.23) \\
31.94 \pm 4.03\end{array}$ \\
\hline p-values & $<0.001^{b}$ & $<0.001^{b}$ & $<0.001^{b}$ & $<0.001^{b}$ \\
\hline \multicolumn{5}{|l|}{ Income } \\
\hline $\begin{array}{l}B a d \\
(n=26)\end{array}$ & $\begin{array}{l}31.25 \\
(8.33: 35.42) \\
28.81 \pm 7.01\end{array}$ & $\begin{array}{l}27.78 \\
(15.56: 36.67) \\
26.11 \pm 5.33\end{array}$ & $\begin{array}{l}30.21 \\
(8.33: 33.33) \\
28.13 \pm 5.49\end{array}$ & $\begin{array}{l}29.61 \\
(11.35: 33.69) \\
27.71 \pm 5.47\end{array}$ \\
\hline $\begin{array}{l}\text { Moderate } \\
(n=240)\end{array}$ & $\begin{array}{l}33.33 \\
(17.71: 50) \\
31.64 \pm 3.94\end{array}$ & $\begin{array}{l}27.78 \\
(12.22: 46.67) \\
27.03 \pm 4.25\end{array}$ & $\begin{array}{l}30.21 \\
(14.58: 45.83) \\
29.61 \pm 3.67\end{array}$ & $\begin{array}{l}29.79 \\
(18.79: 47.52) \\
29.48 \pm 3.31\end{array}$ \\
\hline $\begin{array}{l}\text { Good } \\
(n=132)\end{array}$ & $\begin{array}{l}33.33 \\
(18.75: 50) \\
32.84 \pm 4.12\end{array}$ & $\begin{array}{l}28.89 \\
(16.67: 50) \\
28.87 \pm 4.39\end{array}$ & $\begin{array}{l}30.21 \\
(16.67: 50) \\
30.72 \pm 3.74\end{array}$ & $\begin{array}{l}30.50 \\
(19.15: 48.23) \\
30.85 \pm 3.45\end{array}$ \\
\hline p-values & $<0.002^{b}$ & $<0.001^{b}$ & $<0.003^{b}$ & $<0.001^{b}$ \\
\hline
\end{tabular}

Dat a are expressed as median (minimum: maximum), mean \pm standard deviation.

A difference has been detected in $\mathrm{HL}$ scale scores in terms of education. In the sub-group analysis of health service score, it has been detected that the scores of the participants with education level of primary school and lower was lower than those who are high school, associate and higher graduates (respectively $p<0.001$ and $p<0.001)$. Scores of secondary school graduates

It has been observed that scores of secondary school graduates were lower than high school, associate and higher education graduates (respectively $p<0.001$ and $p<0.001)$. In the sub-group analysis of health allowance score, it has been detected that, the scores of the participants with primary school and lower education levels were lower than high school, associate and higher education graduates (respectively $p=0.008$ and $p<0.001)$. It has been observed that were lower than high school, associate and higher graduates (respectively $p=0.029$ and $p=0.003$ ). In the sub-group analysis of disease prevention scores, it has been detected that the scores of the participants with primary school and lower education levels were lower than high school, associate and higher education graduates (respectively $p<0.001$ and $p<0.001$ ).

scores of secondary school graduates were lower than high school, associate and higher education graduates (respectively $\mathrm{p}=0.029$ and $\mathrm{p}<0.001$ ). In the sub-group analysis made for general scale score, it has been detected that the scores of the participants with primary school and lower education levels were lower than high school, associate and higher education graduates (respectively $p<0.001$ and $p<0.001$ ). It has been observed that the scores of secondary school 
graduates were lower than high school, associate and higher education graduates (respectively $p=0.001$ and $\mathrm{p}<0.001)$.

A difference has been observed in $\mathrm{HL}$ scale scores in terms of income level. In the sub-group analysis of health service score, it has been detected that the scores of the participants with high income level were higher than those with middle- or low-income level (respectively $p=0.008$ and $p=0.017$ ). In the sub-group analysis of disease prevention score it has been detected that the scores of the participants with high income level were higher than those with middle- or low-income level (respectively $p<0.001$ and $p=0.023$ ). In the sub-group analysis of health allowance score it has been detected that the scores of the participants with high income level were higher than those with middle- or low-income level (respectively $p=0.002$ and $p=0.020$ ). In the sub-group analysis of general scale score it has been detected that the scores of the participants with high income level were higher than those with middle- or low-income level (respectively $p<0.001$ and $p=0.010)$.

A difference has been detected in disease prevention score in terms of breastfeeding duration. Disease prevention score of the women who had breastfed their children for 0-12 months was higher than those who had never breastfed or breastfed for more than $>12$ months (respectively $p=0.025$ and $p=0.034$ ).

Relationship between the participants' health literacy status and variables about delivery is given in Table 4. No difference was detected between two groups in terms of delivery parameters when their health literacies were categorized as good and bad.

\section{Table 4. Health Literacy Groups and Obstetric Variables}

\section{Health Literacy}

\begin{tabular}{|c|c|c|c|c|c|}
\hline & $\mathrm{n}$ & $\begin{array}{l}\text { Inadequate/ } \\
\text { Limited }\end{array}$ & $\mathrm{n}$ & $\begin{array}{l}\text { Adequate/ } \\
\text { Excellent }\end{array}$ & p-values \\
\hline \multicolumn{6}{|c|}{ Oral Glucose Tolerance Test } \\
\hline Yes & \multirow[t]{2}{*}{368} & $204(\% 55,4)$ & \multirow[t]{2}{*}{20} & $14(\% 46,7)$ & \multirow[t]{2}{*}{$0,353^{\mathrm{a}}$} \\
\hline No & & $164(\% 44,6)$ & & $16(\% 53,3)$ & \\
\hline \multicolumn{6}{|c|}{ Influenza Vaccination During Pregnancy } \\
\hline Yes & \multirow[t]{2}{*}{368} & $6(\% 1,6)$ & \multirow[t]{2}{*}{30} & $1(\% 3,3)$ & \multirow[t]{2}{*}{$0,425^{\mathrm{b}}$} \\
\hline No & & $362(\% 98,4)$ & & $29(\% 96,7)$ & \\
\hline \multicolumn{6}{|c|}{ Tetanus Vaccination During Pregnancy } \\
\hline Yes & \multirow[t]{2}{*}{368} & $264(\% 71,7)$ & \multirow[t]{2}{*}{30} & $21(\% 70)$ & \multirow[t]{2}{*}{$0,839^{\mathrm{a}}$} \\
\hline No & & $104(\% 28,3)$ & & $9(\% 30)$ & \\
\hline \multicolumn{6}{|l|}{ Delivery } \\
\hline Spontaneous Vaginal & \multirow[t]{2}{*}{302} & $170(\% 56,3)$ & \multirow[t]{2}{*}{24} & $15(\% 62,5)$ & \multirow[t]{2}{*}{$0,555^{\mathrm{a}}$} \\
\hline Caesarean section & & $132(\% 43,7)$ & & $9(\% 37,5)$ & \\
\hline \multicolumn{6}{|l|}{ Breastfeeding } \\
\hline Yes & 368 & $252(\% 68,5)$ & 30 & $21(\% 70)$ & $0,863^{\mathrm{a}}$ \\
\hline
\end{tabular}




\begin{tabular}{|c|c|c|c|c|c|}
\hline $\mathrm{No}$ & & $116(\% 31,5)$ & & $9(\% 30)$ & \\
\hline \multicolumn{6}{|c|}{ Contraception } \\
\hline Yes & \multirow[t]{2}{*}{368} & $252(\% 68,5)$ & \multirow[t]{2}{*}{30} & $21(\% 70)$ & \multirow[t]{2}{*}{$0,863^{\mathrm{a}}$} \\
\hline No & & $116(\% 31,5)$ & & $9(\% 30)$ & \\
\hline \multicolumn{6}{|c|}{ Double Screening Test } \\
\hline Yes & \multirow[t]{2}{*}{367} & $173(\% 47,1)$ & \multirow[t]{2}{*}{30} & $15(\% 50)$ & \multirow[t]{2}{*}{$0,763^{\mathrm{a}}$} \\
\hline No & & $194(\% 52,9)$ & & $15(\% 50)$ & \\
\hline \multicolumn{6}{|c|}{ Triple Screening Test } \\
\hline Yes & \multirow[t]{2}{*}{368} & $157(\% 42,7)$ & \multirow[t]{2}{*}{30} & $11(\% 36,7)$ & \multirow[t]{2}{*}{$0,523^{\mathrm{a}}$} \\
\hline $\mathrm{No}$ & & $211(\% 57,3)$ & & $19(\% 63,3)$ & \\
\hline
\end{tabular}

Data is given as $\mathrm{n}(\%),{ }^{\mathrm{a}}$ : Chi-square test, ${ }^{\mathrm{b}}$ :Fisher'in exact chi-square test

\section{Discussion}

As a result of this research, it has been detected that health literacy level of the women in reproductive age living in our region was adequate/excellent at a rate of $7.5 \%$. HL disease prevention scores of the mothers who breastfed their babies for 12 months were found higher than those who never breastfed or breastfed for more than 12 months. Health literacy was not found affective only in OGTT implementation in pregnancy and tetanus and influenza vaccination during pregnancy, which are among obstetric decisions. It was observed that $\mathrm{HL}$ scores of the participants who had undergone double screening test were higher in disease prevention. We have not observed any relationship between the type of delivery and $\mathrm{HL}$ scores. Likely, no relationship was detected between $\mathrm{HL}$ and contraception.

As a result of this research, it has been detected that health literacy level of the women in reproductive age living in our region was adequate/excellent at a rate of $7.5 \%$. In another study, health literacy was found optimal in pregnant women at a rate of $98.2 \%$ (15). Lee et al. have detected in their study that nearly half of the women have adequate $\mathrm{HL}$ level (16). Whereas in our study, health literacy was found to be low in women in reproductive age. The fact that the questionnaire used for this study is different may partly be the reason for different results, but this difference between the results causes us to approach this explanation with suspicion.

Health literacy disease prevention scores of the mothers who had breastfed their babies for 12 months were found higher than those who had never breastfed or breastfed for more than 12 months. In conformity with our study, Vila-Candel et al. have detected in their study that early cessation of breastfeeding was associated with low HL (17). In another research, it was defended that maternal health literacy must be improved to increase breastfeeding self-efficacy (18). Considering the importance of breast milk for baby, it will be understood how valuable the improvement of maternal $\mathrm{HL}$ is for maternal and infant health.

It was detected that the $\mathrm{HL}$ disease prevention score of the participants who had undergone double screening test was higher than those who had not. There are similar studies in the literature about this issue (19). Rejection of screening Down Syndrome and other genetic diseases during pregnancy increases as 
HL level decreases. Further studies are needed in this subject.

No relation was detected between $\mathrm{HL}$ and contraception. In the studies, it has been demonstrated that contraception method usage and level of knowledge about contraception decreases with low $\operatorname{HL}(20,21)$. This can be explained with few cases with adequate $\mathrm{HL}$ level in our research.

As a conclusion, the rates of health literacy are quite low in women of reproductive age living in our region. The impact of health literacy on obstetric decisions is shown in the study. Improving health literacy in women will have a direct impact on family health especially in terms of disease prevention.

\section{REFERENCES}

1. Kohan S, Mohammadi F, Yazdi M, Dadkhah A. Evaluation of relationship between reproductive health literacy and demographic factors in women. Journal of Health Literacy. 2018; 3(1): 20-29.

2. Zibellini J, Muscat DM, Kizirian N, Gordon A. Effect of health literacy interventions on pregnancy outcomes: A systematic review. Women and Birth. 2021; 34(2): 180-186.

3. Khorasani EC, Sany SBT, Orooji A, Ferns G, Peyman $\mathrm{N}$. Health literacy in Iranian women: a systematic review and meta-analysis. Iranian Journal of Public Health, 2020; 49(5): 860.

4. (Lindau ST, Tomori C, Lyons T, Langseth L, Bennett $\mathrm{CL}$, Garcia P. The association of health literacy with cervical cancer prevention knowledge and health behaviors in a multiethnic cohort of women. American journal of obstetrics and gynecology. 2002; 186(5): 938-943.)

5. (Kim K, Han HR. Potential links between health literacy and cervical cancer screening behaviors: a systematic review. Psycho-Oncology. 2016; 25(2): 122-130.)

6. Sentell T, Braun KL, Davis J, Davis, T. Health literacy and meeting breast and cervical cancer screening guidelines among Asians and whites in California. Springerplus. 2015; 4(1): 1-9.

7. Cho RN, Plunkett BA, Wolf MS, Simon CE, Grobman WA. Health literacy and patient understanding of screening tests for aneuploidy and neural tube defects. Prenatal Diagnosis: Published in Affiliation With the International Society for Prenatal Diagnosis. 2007; 27(5): 463-467.

8. Delanoë, A., Lépine, J., Portocarrero, et al. Health literacy in pregnant women facing prenatal screening may explain their intention to use a patient decision aid: a short report. BMC research notes. 2016; 9(1): 17.

9. Senol D, Göl I, Ozkan S. The effect of health literacy levels of pregnant women on receiving prenatal care: a cross-sectional descriptive study. Int J Caring Sci. 2019; 1717-1724.

10. Castro-Sánchez E, Vila-Candel R, Soriano-Vidal FJ, Navarro-Illana E, Díez-Domingo J. Influence of health literacy on acceptance of influenza and pertussis vaccinations: A cross-sectional study among Spanish pregnant women. BMJ open. 2018; 8(7): e022132.

11. Dongarwar D, Salihu HM. Influence of sexual and reproductive health literacy on single and recurrent adolescent pregnancy in Latin America. Journal of 
pediatric and adolescent gynecology. 2019; 32(5): 506-513.

12. Lori JR, Dahlem CHY, Ackah JV, Adanu RM. Examining antenatal health literacy in Ghana. Journal of Nursing Scholarship. 2014; 46(6): 432-440.

13. (Kilfoyle KA, Vitko M, O'Conor R, Bailey SC. Health literacy and Women's reproductive health: a systematic review. Journal of women's health. 2016; 25(12): 1237-1255.)

14. AYDIN D, ABA YA. Annelerin Sağlık Okuryazarlığı Düzeyleri ile Emzirme Öz-Yeterlilik Algıları Arasındaki İlişki. Dokuz Eylül Üniversitesi Hemşirelik Fakültesi Elektronik Dergisi. 2019; 12(1): 31-39.

15. Hakkak $H$, Joveini $H$, Rajabzadeh $R$, Robatsarpooshi D, Tori N, Haresabadi M, Hosseini S. Health literacy level and related factors among pregnant women referring to bojnord health centers in 2017. International Journal of Pharmaceutical Research. 2019; 11(1): 152-158.

16. Lee HY, Lee J, Kim NK. Gender differences in health literacy among Korean adults: do women have a higher level of health literacy than men?. American journal of men's health. 2015; 9(5): 370-379.

17.Vila-Candel R, Soriano-Vidal FJ, Mena-Tudela D, Quesada JA, Castro-Sánchez E. Health literacy of pregnant women and duration of breastfeeding maintenance: A feasibility study. Journal of Advanced Nursing. 2021; 77(2): 703-714.

18. Charoghchian Khorasani E, Peyman N, Esmaily H. Relations between breastfeeding self-efficacy and maternal health literacy among pregnant women. Evidence Based Care. 2017; 6(4): 18-25.

19. Shea TL. Health Literacy, Understanding, and Decisional Satisfaction in Women's Decision-Making for Prenatal Aneuploidy Screening. The University of North Carolina at Greensboro. 2018.

20.Yee LM, Simon MA. The role of health literacy and numeracy in contraceptive decision-making for urban Chicago women. Journal of community health. 2014; 39(2): 394-399.

21. El-Ibiary SY, Youmans SL. Health literacy and contraception: a readability evaluation of contraceptive instructions for condoms, spermicides and emergency contraception in the USA. The European Journal of Contraception \& Reproductive Health Care. 2007; 12(1): 58-62. 